\title{
Pemodelan Simulasi Tabung Penyerap Energi Crash Box Sebagai Teknologi Keselamatan Pasif Berbasis Software FEM (Finite Elemen Methode)
}

\section{(Simulation modeling on crashworthiness tube as passive safety technology base on FEM software (finite element method))}

\author{
Willy Artha Wirawan ${ }^{1 *}$, Adya Aghastya ${ }^{1}$, Septiana Widi Astuti ${ }^{1}$, Natriya Faisal \\ Rachman $^{1}$, Suprapto ${ }^{2}$, Yustina Titin Purwantiningsih ${ }^{2}$ \\ ${ }^{1}$ Politeknik Perkeretaapian Indonesia Madiun, Jalan Tirta Raya, Madiun (63129) Indonesia \\ Email: willy@pengajar.ppi.ac.id,adya@ppi.ac.id, septiana@ppi.ac.id,natriya@pengajar.ppi.ac.id \\ ${ }^{2}$ Akademi Angkatan Udara, Jl. Raya Solo - Yogyakarta, Kalasan, Sleman, Yogyakarta (55281) Indonesia \\ Email:praptowetan@gmail.com, yustinatitinpurwantiningsih@gmail.com
}

\begin{abstract}
A crash box is one of the absolute safeties in transportation that functions as a means of absorbing impact energy to reduce injuries to drivers and passengers due to collisions or accidents. This study aims to determine the value of energy absorption and the resulting deformation pattern on the crash box in the form of a one-segment circular tube. The method in this study uses a quasiexperimental using finite element-based simulation software (finite element method). The variables in this study include a tube length of $300 \mathrm{~mm}$ with variations in the thickness of $1,5 \mathrm{~mm}$ and $3 \mathrm{~mm}$ and a tube diameter of $120 \mathrm{~mm}$. A quasi-static collision test will be carried out with an impactor with a mass of $200 \mathrm{~kg}$ and a speed of $10 \mathrm{~m} / \mathrm{s}$. The simulation on the crash box is observed based on the value of energy absorption, reaction force, and the formed deformation pattern. The simulation results show that the highest energy absorption value is found in the $3 \mathrm{~mm}$ thick crash box of 790000 Joules. The reaction force of $230000 \mathrm{~N}$. It can be seen that the deformation pattern formed tends to bend in the 1,5 mm thick crash box and forms a concertina pattern on the thick crash box is $3 \mathrm{~mm}$..
\end{abstract}

Keywords - Energy absorbing tube, Crash box, Passive safety, Finite element method

Abstrak-Crash box adalah salah satu komponen keselamatan pasif pada berbagai transportasi yang berfungsi sebagai perangkat penyerap energi tumbukan untuk mengurangi terjadinya cidera pada pengemudi maupun penumpang akibat tabrakan atau kecelakaan. Pada penelitian ini bertujuan untuk mengetahui nilai penyerapan energi dan pola deformasi yang dihasilkan pada crash box yang berbentuk tabung lingkaran satu segmen. Metode pada penelitian ini menggunakan eksperimen semu menggunakan simulasi software berbasis elemen hingga (finite elemen methode). Variable pada penelitian meliputi panjang tabung $300 \mathrm{~mm}$ dengan variasi tebal 1,5 dan $3 \mathrm{~mm}$ dan diameter tabung sebesar $120 \mathrm{~mm}$. eksperimental semu crash box akan dilakukan uji tabrak quasi static dengan impactor masa $200 \mathrm{~kg}$ dan kecepatan $10 \mathrm{~m} / \mathrm{s}$. Simulasi pada crash box diobservasi berdasarkan nilai serapan energi, force reaction dan pola deformasi yang terbentuk. Hasil simulasi dapat diketahui bahwa nilai serapan energi tertinggi terdapat pada crash box tebal $3 \mathrm{~mm}$ sebesar 790000 Joule dan force reaction $230000 \mathrm{~N}$. Dapat dilihat bahwa pola deformasi yang terbentuk cenderung buckling pada crash box tebal 1,5 mm dan membentuk pola concertina pada crash box tebal $3 \mathrm{~mm}$.

Kata Kunci-Tabung penyerap energi, Crash box, Keselamatan pasif, Finite elemen methode

\footnotetext{
*Penulis Korespondensi (Willy Artha Wirawan)
}

E-mail: willy@pengajar.ppi.ac.id 


\section{Pendahuluan}

Peningkatan angka kematian akibat kecelakaan pada berbagai moda transportasi darat dan laut yang cuikup tinggi menyebabkan adanya berbagai kebijakan dengan menjadikan keselamatan adalah faktor yang paling utama. Perhatian riset pada bidang teknik keselamatan transportasi menjadikan suatu yang sangat populer khususnya desain sistem ketahanan bebturan. Seiring dengan berkembangnya teknologi beberapa transportasi seperti mobil, kereta dan pesawat terbang telah memasang sistem keamanan pasif agar tahan terhadap benturan [1].

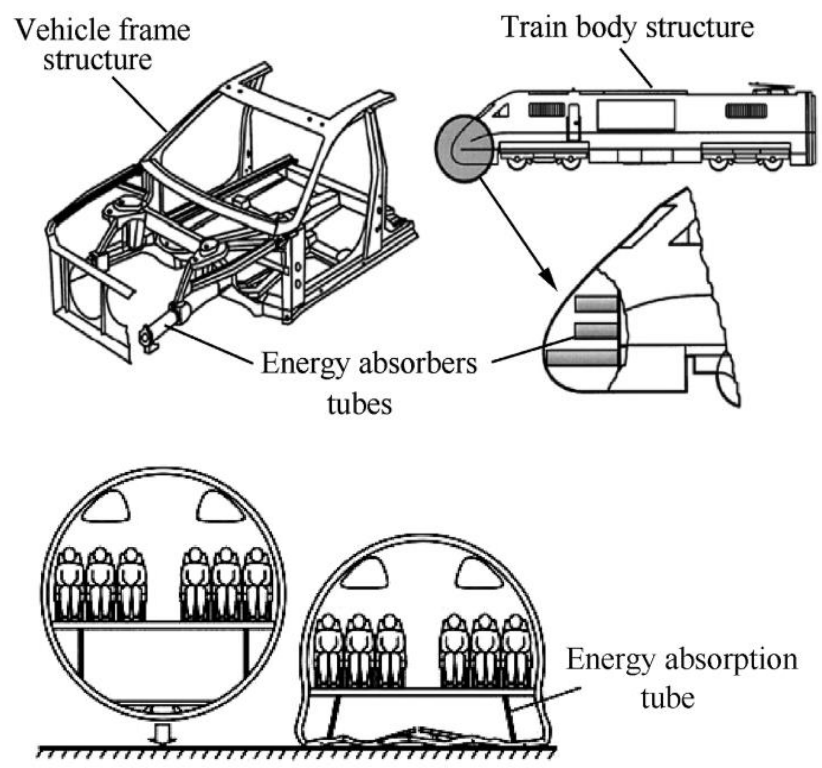

Gambar 1. Sistem keamanan pasif pada berbagai moda transportasi (a) kereta dan mobil (b) pesawat terbang [1]

Crash box adalah salah satu komponen dari perangkat sistem keamanan pasif (passive safety system) pada sebuah transportasi khususnya pada mobil, kereta api dan pesawat terbang. Sistem keselamtan pasif pada crash box akan bekerja ketika terjadi kecelakaan tumbukan sudah tidak dapat lagi terhindarkan [2]. Ketika sebuah sistem keselamtan aktif pada moda transportasi sudah tidak mampu lagi mencegah terjadinya insiden seperti tumbukan maupun jatuh maka sistem ini secara tidak langsung akan mulai aktif [3]. Fungsi dari peralatan ini adalah untuk mengurangi atau meminimalisir adanya cedera maupun luka-luka yang mungkin dialami oleh pengemudi maupun penumpang di dalam transportasi tersebut. Selain itu, pada perangkat crash box berfungsi untuk mencegah terjadinya kerusakan yang lebih fatal pada bagian beberapa transportasi mobil, kereta maupun pesawat yang vital akibat tabrakan frontal. Bahkan pada pengembangan teknologinya crash box ini didesain pada beberapa transportasi seperti kereta api berperan sebagai absorber untuk menyerap sebanyak mungkin adanya energi kenetik selama tabrakan selanjutnya dikendalikan oleh elemen deformasi dan mengurangi gaya yang diterapkan keseluruh rangka atau struktur [4] [5].

Velmurugan et.al. tahun 2009 melakukan penelitian tabung penyerapan energy pada crasbox dengan beberapa bentuk yaitu lingkaran, persegi dan persegi panjang dengan material dan ketebalan yang sama. Hasil penelitian menyatakan bahwa nilai penyerapan energy pada tabung crash box lingkaran mempunyai nilai penyerapan yang paling tinggi dari bentuk lainya [2].

Dari berbagai pernyataan referensi tersebut, mengingat pentingnya crash box sebagai perangkat sistem keselamatan pasif maka pada penelitian ini membahas pemodelan simulasi 
eksperimental semu melalui perangkat simulasi komputer software berbasis Metode Elemen Hingga (Finite Element Method) pada perangkat tabung penyerap energi crash box. Tujuan dari penelitian ini adalah untuk mengetahui berbagai variasi dimensi tebal tabung dan pola deformasi yang terbentuk pada perangkat tersebut sehingga dapat digunakan sebagai referensi dan aplikasi pada berbagai transportasi.

\section{LANDASAN TEORI}

Pada penelitian ini untuk melakukan analisis dan menghitung nilai penyerapan energi, force reaction dan pola deformasi yang telah dihasilkan pada crash box dapat digunakan beberapa parameter persamaan. Harga pembebanan kritis $\mathrm{P}_{\mathrm{cr}}$, diberikan dengan rumus (persamaan Euler) [6] [9].

$$
\operatorname{Pcr}=\frac{\pi^{2} E I}{4 L^{2}}
$$

Dimana :

$\mathrm{Pcr}=$ Beban kritis $(\mathrm{N})$

$\mathrm{E}=$ Modulus elastisitas $(\mathrm{Pa})$

I = Momen inersia penampang lingkaran $\left(\mathrm{m}^{4}\right)$

$\mathrm{L}=$ Panjang kolom $(\mathrm{m})$

Nilai force reaction (beban) tertinggi pada masing-masing model crash box, merupakan persamaan yang digunakan untuk mencari nilai besarnya energi regangan atau usaha. Pada persamaan ini dapat diketahui bahwa energi berbanding lurus dengan beban yang berdampak pada bersarnya nilai beban maka energi yang dihasilkan semakin besar seperti pada rumus berikut [6] [9].

$$
U=W=\int_{0}^{\delta} P(\delta) d \delta
$$

Dimana :

$$
\begin{array}{ll}
U & =\text { Energi Regangan }(\mathrm{J}) \\
W & =\text { Usaha }(\mathrm{J}) \\
P & =\text { Beban }(\mathrm{N}) \\
\delta & =\text { Perpindahan }(\mathrm{m})
\end{array}
$$

Besar energi regangan yang tersimpan adalah sebesar luas daerah yang dibentuk garis linier dengan sumbu $\mathrm{x}$. Besarnya energi regangan yang tersimpan adalah sama dengan usaha yang dilakukan oleh beban pada material menunjukkan diagram beban perpindahan elastis material yang dapat dilihat dengan persamaan berikut [7].

$$
\delta=\frac{P L}{E A}
$$

Sehingga persamaan energi regangan dapat dirumuskan

$$
\mathrm{U}=\frac{P^{2} L}{2 E A}
$$

Dimana :

$\mathrm{P}=$ Beban $(\mathrm{N})$

$\mathrm{L}=$ Panjang material $(\mathrm{m})$

$\mathrm{E}=$ Modulus elastisitas $(\mathrm{Pa})$

$\mathrm{A}=$ Luas penampang $\left(\mathrm{m}^{2}\right)$

\section{Metode Penelitian}

Metode yang telah digunakan pada adalah eksperimental tidak nyata atau semu, yaitu dengan melakukan pengujian simulasi crash box melalui komputer dan menggunakan software yang berbasiskan FEM (Finite Element Method). Tujuan yang hendak dicapai dalam simulasi 
tersebut adalah dapat memprediksi percobaan dari desain crash box yang telah dibuat sebagai perangkat keamanan passive pada transportasi.

Crash box yang digunakan pada penelitian berbentuk tabung lingkaran dengan variable bebas yaitu variasi tebal tabung sebesar $1,5 \mathrm{~mm}$ dan $3 \mathrm{~mm}$. Variable terikat adalah penyerapan energi dan pola deformasi pada desain crash box. Variable terkontrol yaitu pemodelan material billinier hardening isotropic, kecepatan impactor $10 \mathrm{~m} / \mathrm{s}$, diameter luar $120 \mathrm{~mm}$ dan panjang crash box $300 \mathrm{~mm}$. Desain penelitian pada tabung crash box penyerap energi dapat dilihat pada gambar 3 dibawah ini
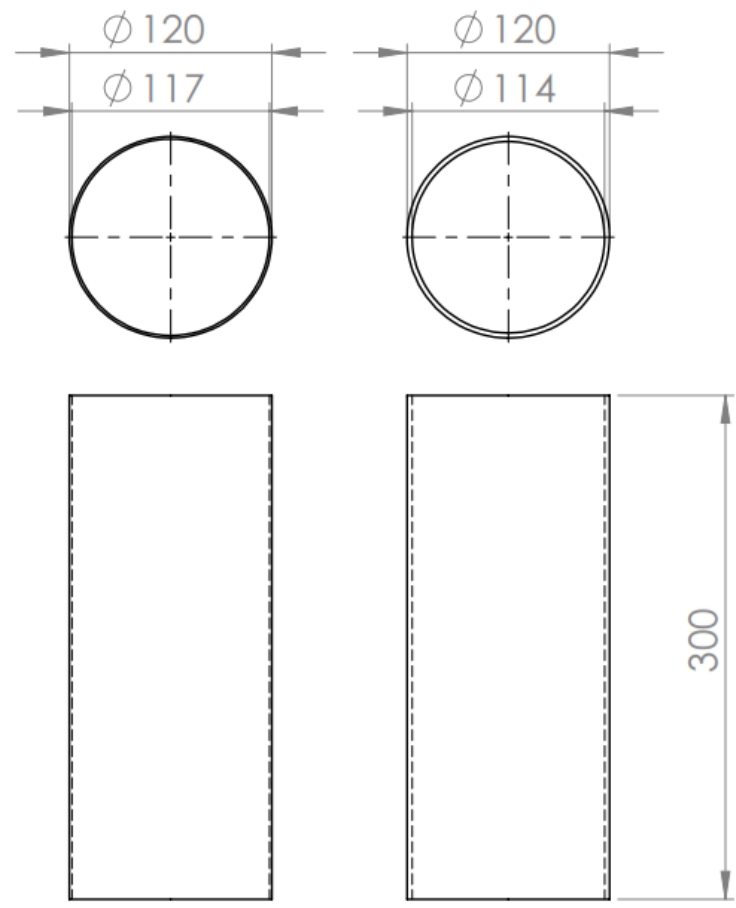

Gambar 3. Desain Crash Box

Material pada crash box menggunakan aluminium tipe $6063 \mathrm{~T} 5$, pada proses simulasi impactor dimodelkan benda yang rigit menabrak body crash box dengan kecepatan gravitasi 9,8 $\mathrm{m} / \mathrm{s}$ dan bagian bawah pemodelan crash box diatur fix support. Pengujian dilakukan dengan metode quasi-static tes untuk mengetahui kemampuan crash box terhadap nilai penyerapan energy. Sifat properties pada material aluminium AI 6063 dapat dilihat pada tabel 1

Tabel 1. Properties Material Al 6063-T5

\begin{tabular}{|c|c|}
\hline \hline Properties & Nilai \\
\hline Density & $2700 \mathrm{~kg} / \mathrm{m}^{3}$ \\
\hline Young's Modulus & $69000 \mathrm{MPa}$ \\
\hline Poisson Ratio & 0,33 \\
\hline Tangent Modulus & $580 \mathrm{MPa}$ \\
\hline Yield Strength & $180 \mathrm{MPa}$ \\
\hline \hline
\end{tabular}

Mesh merupakan pembagian objek menjadi bagian lebih kecil dengan jumlah yang berhingga (finite). Semakin kecil meshing yang digunakan maka hasil perhitungan akan semakin teliti. Pada penelitian ini menggunakan meshing otomatis jenis mechanical sizing curvature ukuran $2 \mathrm{~mm}$ digunakan untuk crash box dan elemen solid hexahedron $300 \mathrm{~mm}$ untuk impactor. 

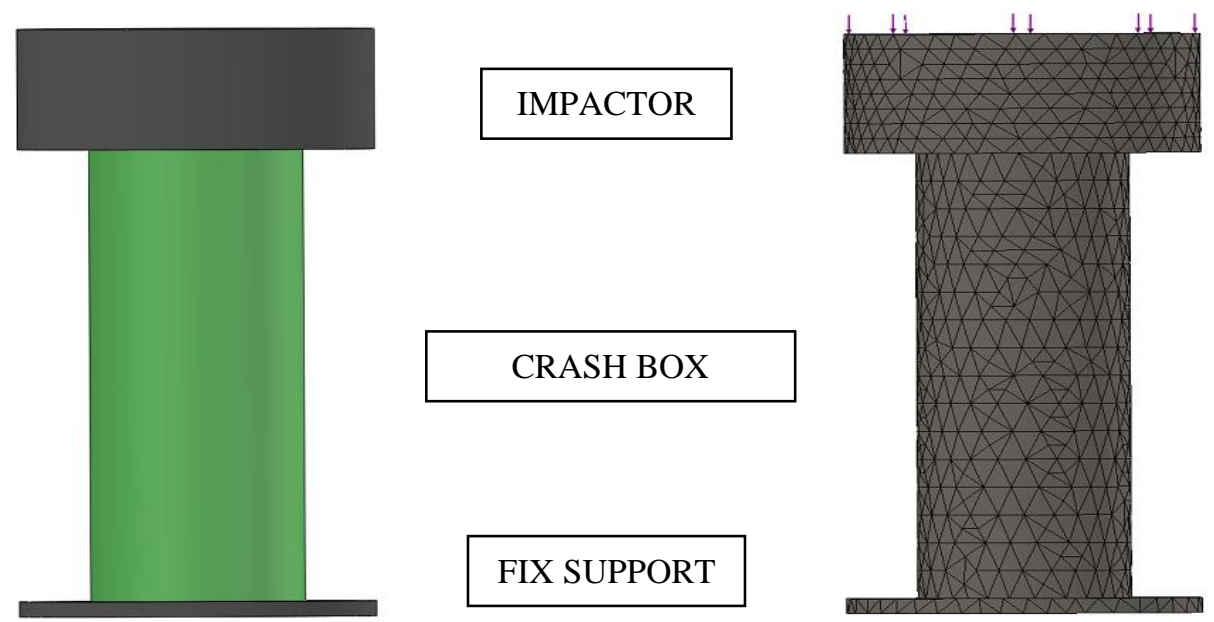

Gambar 3. (a) Simulation condition crash box (b) meshing

\section{HASIL DAN PEMBAHASAN}

Hasil yang didapatkan pada penelitian crash box sebagai perangkat keamanan passive pada transportasi dapat diketahui force reaction, nilai serapan energi dan pola deformasi yang telah dihasilkan pada proses eksperimental semu menggunakan software berbasis FEM (finite elemen methode)

\section{A. Force Reaction}

Force reaction merupakan gaya yang diberikan oleh crash box sebagai reaksi ketika menahan tumbukan dari impactor pada masing-masing variasi tebal crash box $1,5 \mathrm{~mm}$ dan 2 $\mathrm{mm}$ seperti yang ditunjukkan pada gambar 4 sebagai berikut

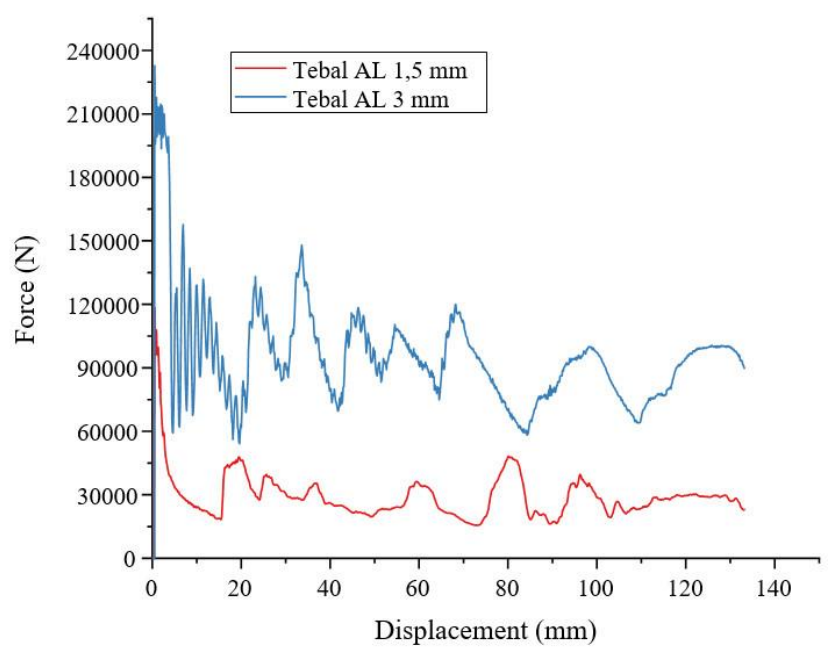

Gambar 4. Force reaction

Gambar 4 force reaction menunjukkan hubungan gaya dengan displacement pada crash box yang telah dilakukan simulasi. Nilai force reaction crash box yang telah dilakukan simulasi uji tabrak dengan pada tebal $1,5 \mathrm{~mm}$ mempunyai nilai lebih rendah $120000 \mathrm{~N}$ jika dibandingkan dengan crash box dengan tebal $3 \mathrm{~mm}$ sebesar $230000 \mathrm{~N}$. Dari grafik hasil simulasi menujukkan bahwa luasan dibawah kurva merupakan serapan energi pada crasbox, dengan luasan yang lebih besar dapat diketahui bahwa crash box dengan tebal $3 \mathrm{~mm}$ mempunyai serapan yang lebih baik. 
Bentuk grafik yang dihasilkan pada crash box dengan tebal 1,5 cenderung mempunyai titik puncak yang lebih sedikit yang berarti bahwa crash box mengalami folding yang rendah hal tersebut telah terkonfirmasi pada pola yang dihasilkan crash box [8] [9].

\section{B. Penyerapan Energi}

Pada saat impactor telah menghantam tabung crash box, energi impact yang terjadi dari impactor akan dikonversikan menjadi energi regangan dan mengakibatkan perubahan bentuk deformasi yang terjadi pada crash box. Energi regangan didapatkan dari luas daerah dibawah kurva yang dapat dilihat pada gambar 5 sebagai usaha yang dilakukan oleh impactor sehingga energi regangan dapat diasumsikan hasil konversi energi kinetik dari tabrakan oleh impactor [10]. Selain dari luas yang berada di bawah kurva, energi regangan juga dapat dilihat secara langsung dari hasil simulasi.

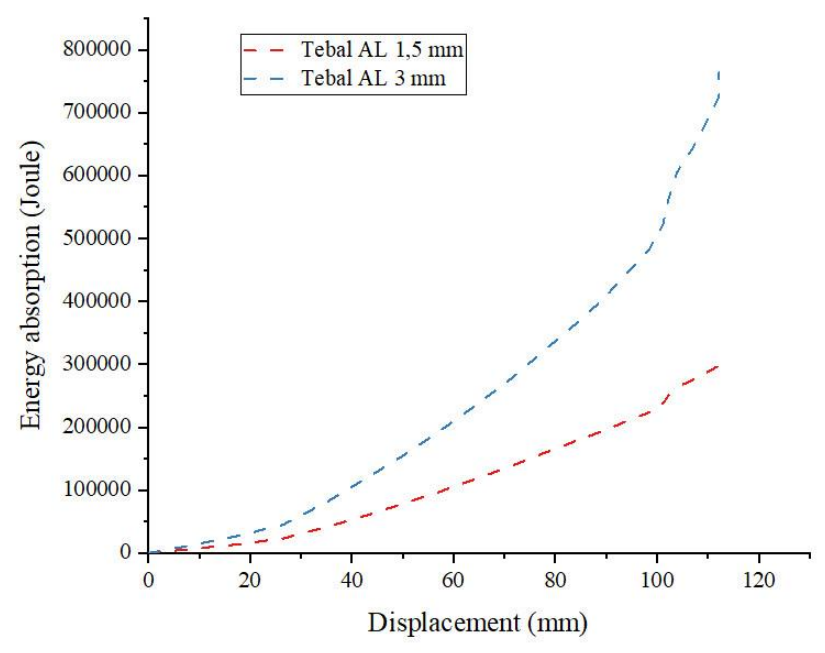

Gambar 5. Nilai penyerapan energi

Gambar 5 merupakan grafik hubungan antara besar energi yang diserap (energy absorption) dengan displacement pada masing masing crash box dengan tebal $1,5 \mathrm{~mm}$ dan 3 $\mathrm{mm}$ pada displacement yang sama. Nilai penyerapan energi terbesar terdapat pada model crash box dengan tebal $3 \mathrm{~mm}$ memiliki nilai penyerapan energi tertinggi sebesar 790000 Joule. Selanjutnya pada crash box dengan tebal $1,5 \mathrm{~mm}$ mempunyai nilai penyerapan energi lebih rendah sebesar 300000 Joule. Nilai rendah penyerapan energi telah terkonfirmasi pada hasil force reaction sebelumnya mempunyai puncak lebih sedikit yang berarti mengalami deformasi yang sedikit dan pola deformasi crash box yang cenderung mengalami buckling [10].

\section{Pola Deformasi}

Gambar 6 merupakan perubahan pola deformasi yang terbentuk selama impactor menghantam crash box. Terlihat bahwa pada model deformasi crash box dengan tebal aluminium 1,5 mm mempunyai bentuk pola deformasi yang tidak sempurna jika dibandingkan dengan crash box dengan tebal aluminium $3 \mathrm{~mm}$. Crash box dengan tebal $1,5 \mathrm{~mm}$ cenderung mengalami buckling, hal tersebut dikarenakan proses deformasi terjadi pada saat impactor menabrak tabung terlebih dahulu pada bagian bahwah tabung mengalami deformasi membentuk pola concertina dan diamond. Seiring dengan meningkatnya beban tabung bagian atas mengalami deformasi diamond dan terjadi buckling sehingga serapan energi cenderung rendah [5] [8].

Crash box dengan ketebalan $3 \mathrm{~mm}$ cenderung mengalami deformasi yang lebih baik, hal tersebut terjadi pada saat impactor menabrak tabung, pada bagian atas 
mengalami pola deformasi concertina kemudian dilanjutkan dengan mode diamond sehingga serapan energi lebih tinggi. Keadaan buckling pada saat tumbukan dapat menyebabkan cras box tidak dapat menyerap energi yang lebih baik [3] [11].

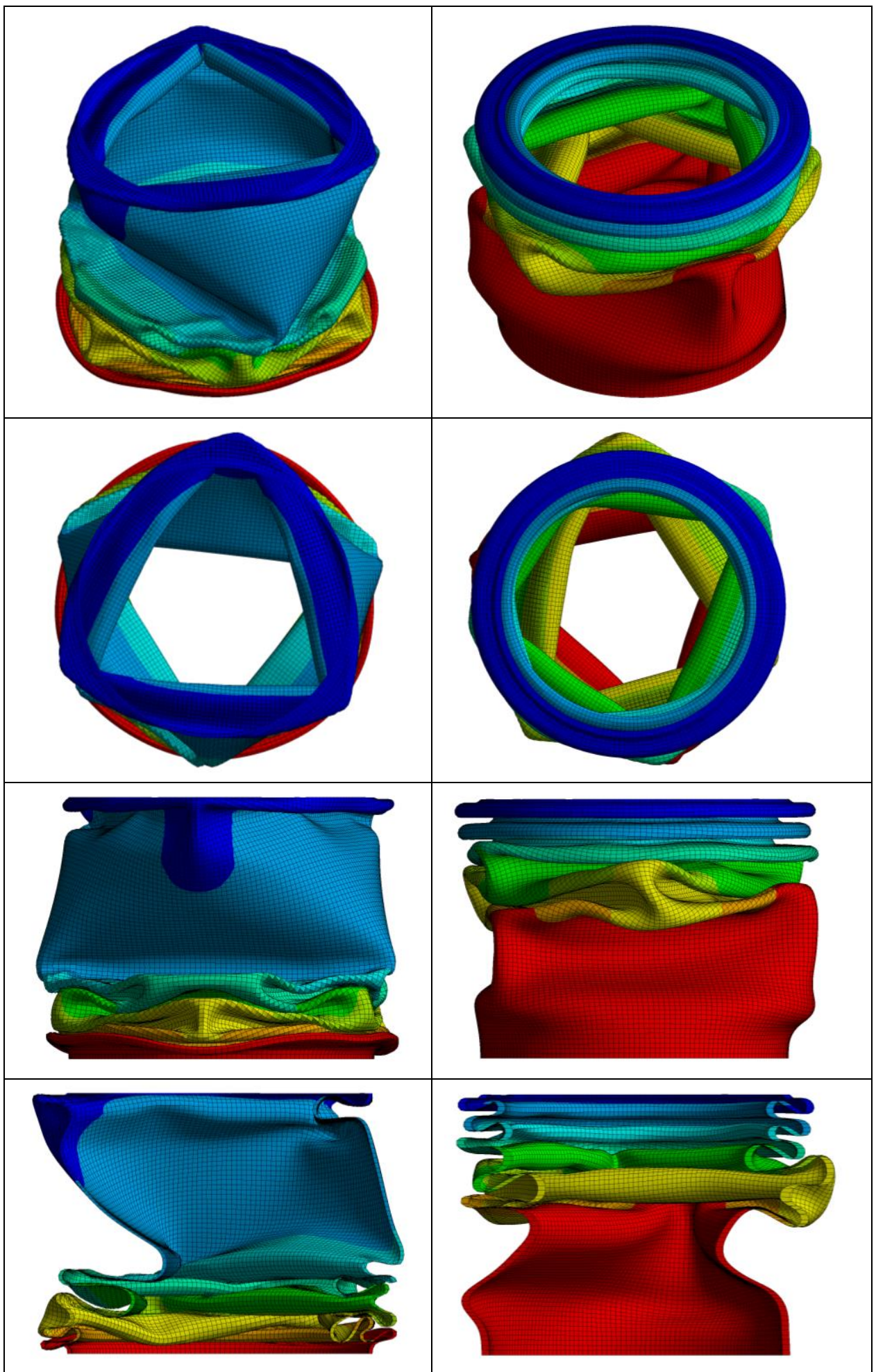

Gambar 6. Pola deformasi crash box 


\section{KeSIMPULAN}

Dari hasil penelitian ini, dapat diperoleh kesimpulan bahwa pemodelan simulasi menggunakan software berbasis FEM (finite elemen methode) pada tabung penyerap energi crash box sebagai teknologi keselamatan pasif diketahui bahwa semakin tebal dinding crash box $3 \mathrm{~mm}$ didapatkan nilai penyerapan energi yang paling tinggi sebesar 790000 Joule. Pola deformasi dengan bentuk buckling terjadi pada crash box tebal 1,5 $\mathrm{mm}$ dan membentuk pola lebih baik pola concertina pada crash box tebal $3 \mathrm{~mm}$. Sebagai saran yang dapat diambil pada penelitian ini adalah perlu dilakukan eksperimen secara nyata atau langsung pada crash box yang telah dilakukan simulasi sehingga dapat dibandingkan data sebagai pengembangan pada penelitian lanjut maupun aplikasinya.

\section{UCAPAN TERIMA KASIH}

Ucapan terima kasih atas terselesaikanya dan terbitnya naskah paper ini pada Seminar Nasional Sains Teknologi dan Inovasi Indonesia tahun 2021 sebagai bagian kolaborasi/kerjasama penelitian antara pusat penelitian dan pengabdian masyarakat P3M politeknik perkeretaapian Indonesia Madiun dengan Akademi Angkatan Udara.

\section{REFERENSI}

[1] Supian, A. B.M., S. M. Sapuan, M. Y.M. Zuhri, E. S. Zainudin, and H. H. Ya. 2018. "Hybrid Reinforced Thermoset Polymer Composite in Energy Absorption Tube Application: A Review." Defence Technology 14 (4): 291-305. https://doi.org/10.1016/j.dt.2018.04.004.

[2] Velmurugan., dan Muralikanan. (2009): Energy Absorption Characteristics of Annealed Steel Tubes Of various Cross Sections in Static And Dynamic Loading. Latin American Journal Of Solids And Structutres, Volume. 6, $2009: 385-412$.

[3] Astuti SW, Wirawan WA, Zulkarnain A, Istiantara DT (2019), Comparison of energy absorption and pattern of deformation material crash box of three segments with bilinear and Johnson Cook approach Journal of Physics: Conference Series $12731 \mathrm{https} / / /$ doi.org/10.1088/1742-6596/1273/1/012078

[4] Choiron MA Sudjito S Hidayati NA (2016), Crash energy absorption of two-segment crash box with holes under frontal load AIP Conference Proceedings 1717050009

[5] L. Morello. L.R. Rossini, G. Pia, A. Tonoli, 2011, The Automotive Body: Volume II: System Design, Springer Science \& Business Media, Berlin

[6] M. Agus Choiron., dkk. (2015): Analisis Penyerapan Energi Dan Pola Deformasi Crash Box Dengan Variasi Sudut Tirus Dinding Crash Box Pada Uji Simulasi Tabrakan Arah Frontal. Malang : Jurnal Rekayasa Mesin Vol. 6, No 1 Tahun 2015 : 75-83.

[7] J. Tanaskovic., dkk. (2014): Experimental Investigations Of The Shrinking - Splitting Tube Collision Energy Absorber, Journal Thin - Walled Structures. University of Belgrade, faculty of Mechanical Engineering, kralije, marije 16, belgrade, Serbia.

[8] Rusinek A, R. Zaera, P. Forquin and J.R. Klepaczko, 2008, Effect of plastic deformation and boundary conditions combined with elastic wave propagation on the collapse site of a crash box. Laboratory of physics and mechanics of materials, France.

[9] Wirawan WA Zulkarnain A Wahjono HB Jamaludin Damayanti AT 2019 The effect of material exposure variations on energy absorption capability and pattern of deformation material of crash box of three segments Journal of Physics: Conference Series 12731 https://doi.org/10.1088/1742-6596/1273/1/012081

[10] X. Zhang, and You, Z., (2014), Energy absorption of thin-walled square tubes with a prefolded origami pattern-part I: geometry and numerical simulation. Journal of applied mechanics vol. 81.

[11] X. Zhang, G. Cheng, Z. You, H. Zhang, (2007), Energy absorption of axially compressed thinwalled square tubes with patterns, Thin-Walled Struct. 45. 737-746 